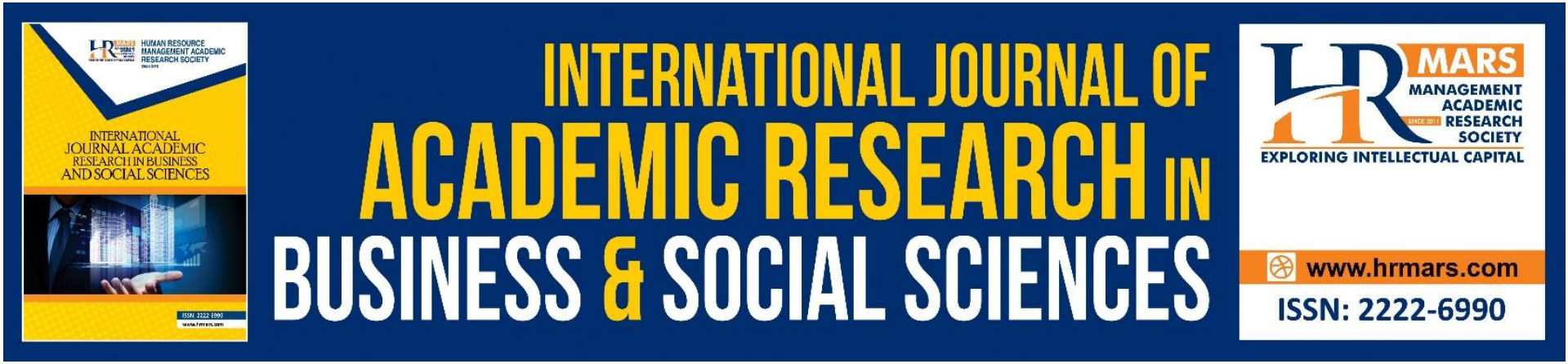

\title{
A Review on the Impact of Work-Life Balance in Reducing Turnover Intention through Work from Home Intervention in Malaysia Real Estate Market
}

Isaac Y. N. Foo and Sabrinah Adam

To Link this Article: http://dx.doi.org/10.6007/IJARBSS/v11-i6/10197

DOI:10.6007/IJARBSS/v11-i6/10197

Received: 11 April 2021, Revised: 13 May 2021, Accepted: 27 May 2021

Published Online: 15 June 2021

In-Text Citation: (Foo \& Adam, 2021)

To Cite this Article: Foo, I. Y. N., \& Adam, S. (2021). A Review on the Impact of Work-Life Balance in Reducing Turnover Intention through Work from Home Intervention in Malaysia Real Estate Market. International Journal of Academic Research in Business and Social Sciences, 11(6), 634-647.

Copyright: (C) 2021 The Author(s)

Published by Human Resource Management Academic Research Society (www.hrmars.com)

This article is published under the Creative Commons Attribution (CC BY 4.0) license. Anyone may reproduce, distribute, translate and create derivative works of this article (for both commercial and non-commercial purposes), subject to full attribution to the original publication and authors. The full terms of this license may be seen

at: http://creativecommons.org/licences/by/4.0/legalcode

Vol. 11, No. 6, 2021, Pg. 634- 647

Full Terms \& Conditions of access and use can be found at http://hrmars.com/index.php/pages/detail/publication-ethics 


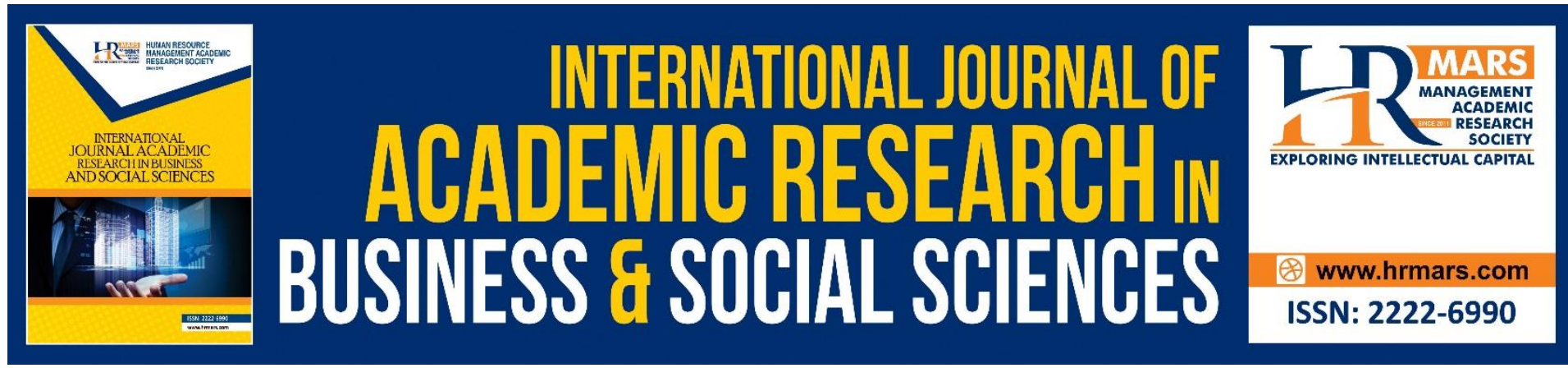

\title{
A Review on the Impact of Work-Life Balance in Reducing Turnover Intention through Work from Home Intervention in Malaysia Real Estate Market
}

\author{
Isaac Y. N. Foo and Sabrinah Adam \\ Azman Hashim International Business School, Universiti Teknologi Malaysia, \\ 81310 Johor Bahru, Johor \\ Email: isaacfooyongnuo@hotmail.com
}

\begin{abstract}
This study aimed to identify on how work from home can serve as a work-life balance intervention that reduced the turnover intention in Malaysia real estate market. Spillover Theory, Border Theory and Maslow's hierarchy of needs are applied as the fundamental concepts of this study, while work-life balance intervention is carried out based on the concept of Lewin's change model. Mixed method approach is applied in this study in order to understand the contradictions between both qualitative and quantitative findings. Meanwhile, data collected is analyzed by qualitative and quantitative analysis to reflect the effectiveness of work from home intervention on improving work-life balance and reducing turnover intention. Result obtained is contradicted to most of the studies' findings, where work from home will assist the workers to achieve work-life balance and reduce turnover intention. This might due to such intervention is not widely accepted yet in Malaysia and the lack of managerial support.
\end{abstract}

Keywords: Work-life Balance, Turnover Intention, Work From Home, Job Satisfaction, WorkLife Balance Initiatives

\section{Introduction}

Real estate market can be considered as one of the most essential industries that driven the development of a country. As this industry focused on improving the landscape, ecosystem and habitats, it can contribute to economic stability by creating more job opportunities, uniting the communities and maintaining the environments value (A. R. Brouwer, n.d.). In related to Malaysia context, the government is giving much attention to improve the condition of property development market via several policies such as Home Ownership Campaign (HOC) (PropertyGuru International (Malaysia) Sdn Bhd, 2020) and Fund My Home Scheme (FundMyHome, 2019).

Although Dzulkifly (2020) stated that number of fresh graduates are expected to be around 300,000 in year 2020, which the increasing number of fresh graduates in Malaysia and allowed this market to acquire the suitable fresh employees for the particular jobs, but the economic recession due to the COVID-19 pandemic has led to a higher job demand in certain 
industries such as IT, software and manufacturing industries has shifted new talents' attention away from this industry new recruitments (Arumugam, 2020).

Furthermore, the aggressive poaching strategies due to the fierce competition among local property developers (EdgeProp.my, 2020), economic downfall of the real estate market (Khoo \& Chung, 2020) and widespread hiring freeze and decrement in salary (Supriya, 2020) have made the talent acquisition in real estate market to be more difficult compared to the previous time. As such, this has brought to the study attention in reducing the turnover intention and achieving work-life balance among real estate market employees before the situation is getting worse. The research questions in this study are formulated as following:

RQ1: Does work-life imbalance is the main factor that led to employee turnover intention in real estate market?

RQ2: What approaches can be taken to reduce work-life imbalance in real estate market due to long working hour and rigid company working structure?

RQ3: What can be proposed and intervened to reduce work-life imbalance in real estate market due to long working hour and rigid company working structure?

\section{Literature Review}

Interestingly, the application of work-life balance initiatives does not guarantee definite positive outcomes nor negative outcomes to the employee turnover intention. For example, under Oosthuizen, Coetzee and Munro (2016); Arshad and Puteh (2015) and Thakur and Bhatnagar (2017) studies, work-life balance is negatively correlated to employee turnover intention, where employees are more willing to stay with the company when they achieve their work-life balance through initiatives such as work from home or flexible working hour. This is because the employees are allowed to allocate more time to their love one or personal time through such family friendly policies, which will make them to be more committed toward their job and achieve a higher sense job satisfaction that make them hard to leave the company (Akinyele, Peters \& Akinyele, 2016). According to Hobbs, Klachky and Cooper (2020), turnover intention may be reduced when workers are able to commit to family matters. Thus, the study suggested that reasonable number of vacations, flexible work arrangement and personal freedom at work should be emphasized in order to reduce turnover intention.

On the other hand, certain researchers such as Sarker, Ahuja and Sarker (2018), Rasheed, Iqbal and Mustafa (2018); Takeuchi (2017) oppose on such findings as they mentioned that the application of work-life balance initiatives does not have significant effect on employee turnover intention. In fact, the application of such initiatives might lead to a worsen scenario on the turnover intention. This may due to the less adoption of work-life balance initiatives in the workplace, the "family first" culture in the country or the work colonializing in non-work life by flexible working hour. Kopperud, Nerstad and Dysvik (2020) stated that turnover intention might occur when work-home spillover occurred, where negative spillover effect has the strongest direct effect on the turnover intention and overwhelm positive spillover effect most of the time, while such burnout in work-family conflict will lead to emotional exhaustion among employees instead of keeping them with the company (Rajendran, Watt \& Richardson, 2020). 


\section{Spillover Theory}

Carlson et al. (2019) stated that this theory proposed that employees tend to carry forward the feelings, emotions and attitudes they have either from work to home or from home to work, where work or home will influence to each other positively or negatively depends on the satisfaction and achievement in that particular domain. The main factors of spillover effect from home to work can be based on five major categories, namely the material resource (Salary), formal and informal training (Developmental experiences), interpersonal relationship (Supervisor support), employees' degree of control over their daily working hours (Schedule control) and individual abilities to cope, perform and success (Self-efficacy), while spillover effect from home to work is identified based on marital satisfaction and spouse's commitment to work as shown in the figure below.

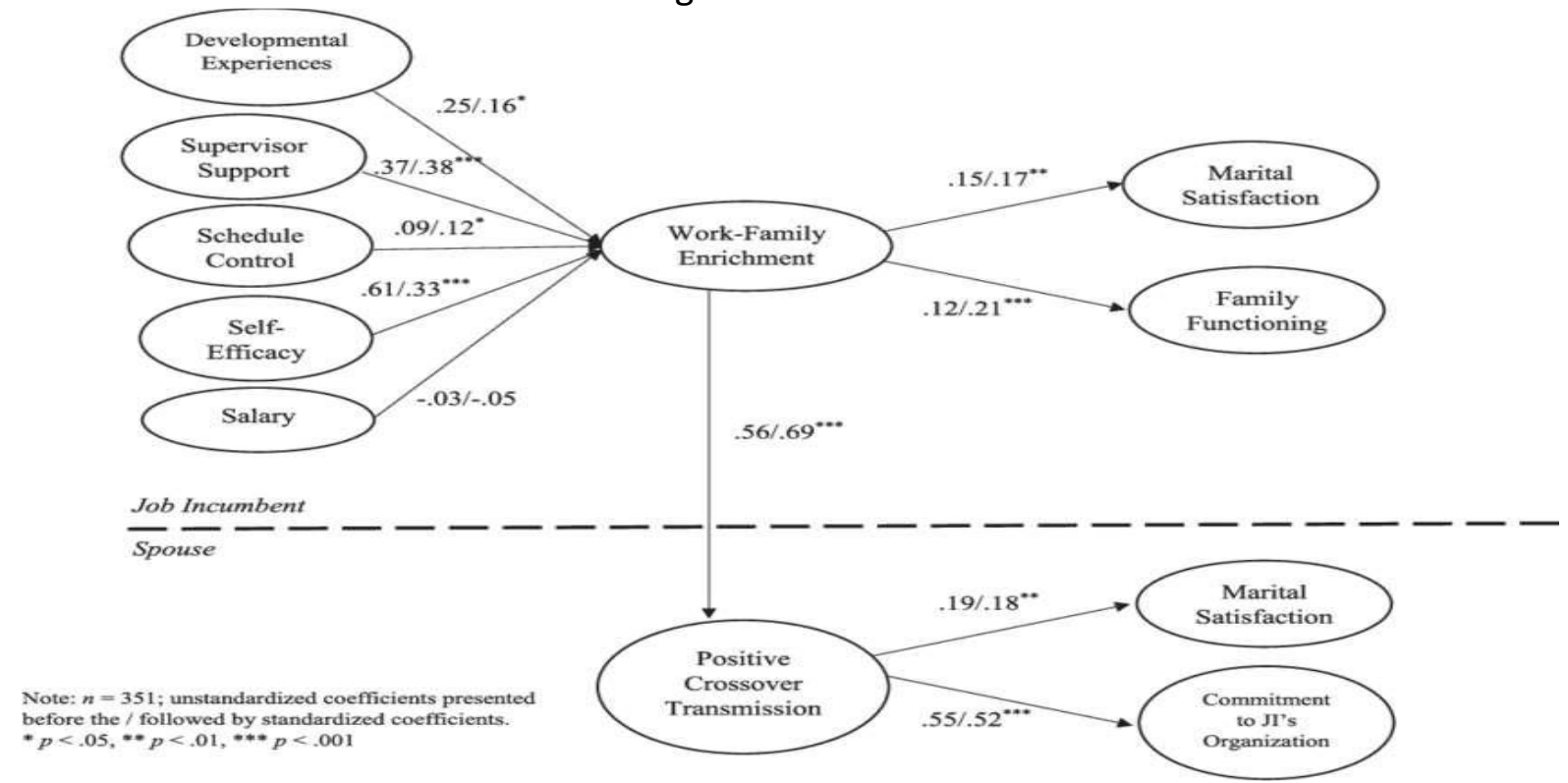

Figure 1: Spillover theory model (Carlson et al., 2019).

\section{Border Theory}

Sarker, Ahuja and Sarker (2018) stated that this theory suggested that work and home can be defined as two different domains that made up own borders that restricted the entrance from other domains. The borders' strength is determined by the degree of flexibility, permeability and blending. Finally, there are border keepers that encouraged or restricted the movement of border crossers from work domain to home domain or the other way round. A higher degree of flexibility, permeability and blending will form a weaker border, which does not guarantee a reduction in work-life conflict and turnover intention, but just indicated that a domain can easily influence another domain and vice versa. The theory model will be illustrated by the figure below. 


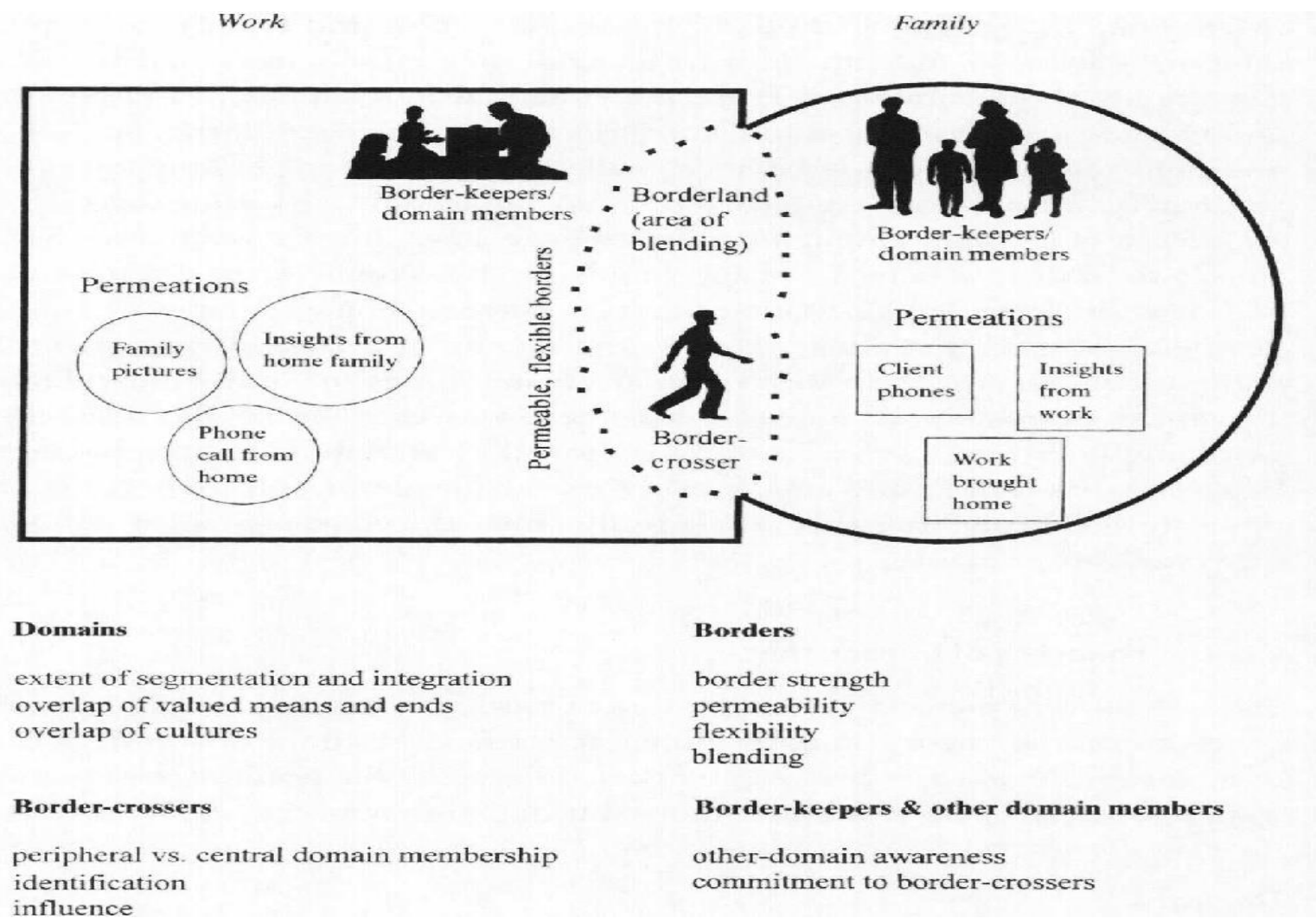

Figure 2: Border theory model (Clark, 2000).

\section{Maslow's Hierarchy of Needs}

Proposed by Abraham Maslow in his writing "A Theory of Human Motivation", Einstein, Addams and Roosevelt (2016) stated that this theory justified that basic level of needs must be fulfilled first in order to reach the higher level of needs in life, which started from the level of physiological, followed by safety, love and belonging, esteem and finally the selfactualization. In related to this theory, organizations can help to realize employees' need by guaranteeing stable job to fulfill physiological and safety needs, showing caring and acceptance from the organizations towards different individuals' characteristics to fulfill love and belonging needs and providing opportunities and freedom to the employees to fulfill esteem and self-actualization needs, which helped them to commit to their jobs and to lower employee turnover intention ultimately as shown in the below figure. 


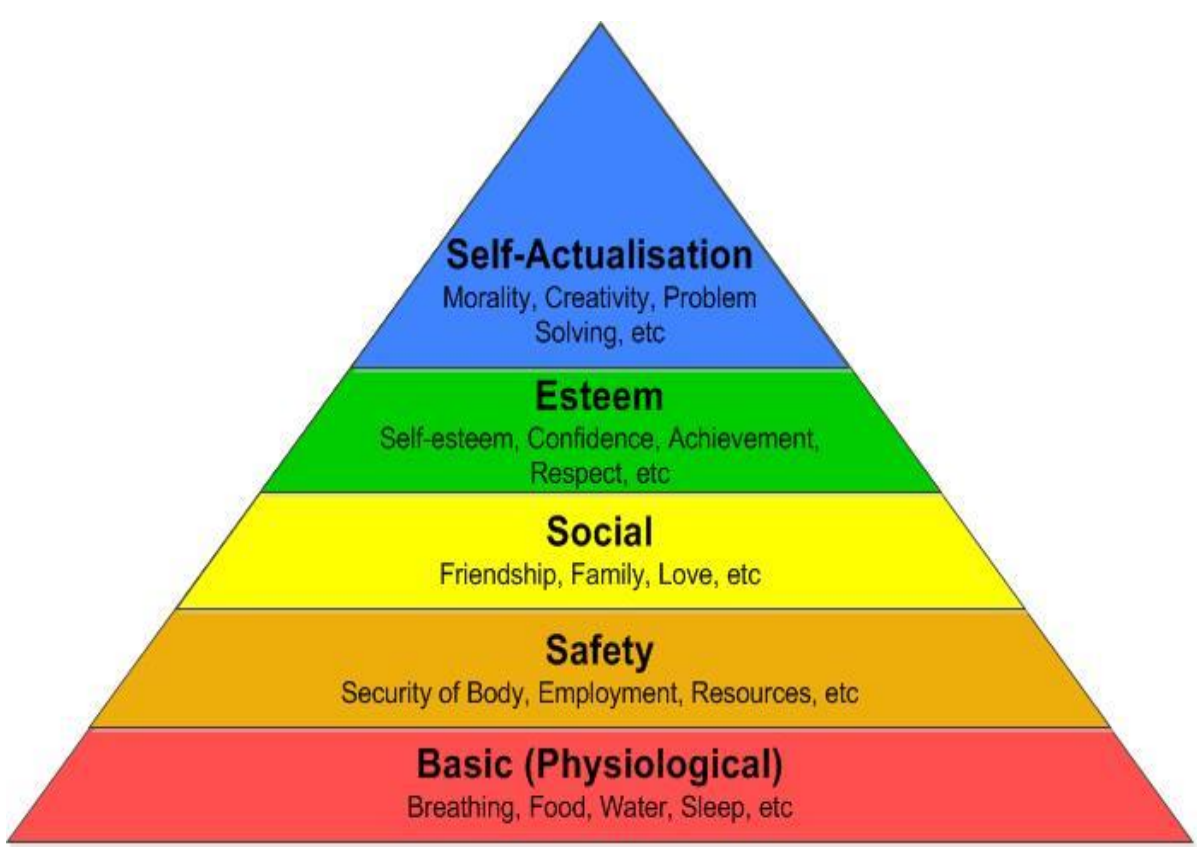

Figure 3: Maslow's hierarchy of needs pyramid (Einstein, Addams \& Roosevelt, 2016).

\section{Lewin's Change Model}

Cummings, Bridgman and Brown (2016) stated that this model can be treated as the fundamental tactic in managing change, which consisted of three main procedures of unfreeze, change and refreeze. A sense of urgency and awareness on the need of is created under the unfreeze stage to get the parties involved ready for changes. New behaviors, processes and ways of thinking to the target group are implemented in change stage afterwards, followed by the refreeze stage when people accepted and start to practice the new status quo consistently, where close monitoring has to be made in order to guarantee the change is not lost. The concept of this change model illustrated by the figure below.

Input Transformation Output

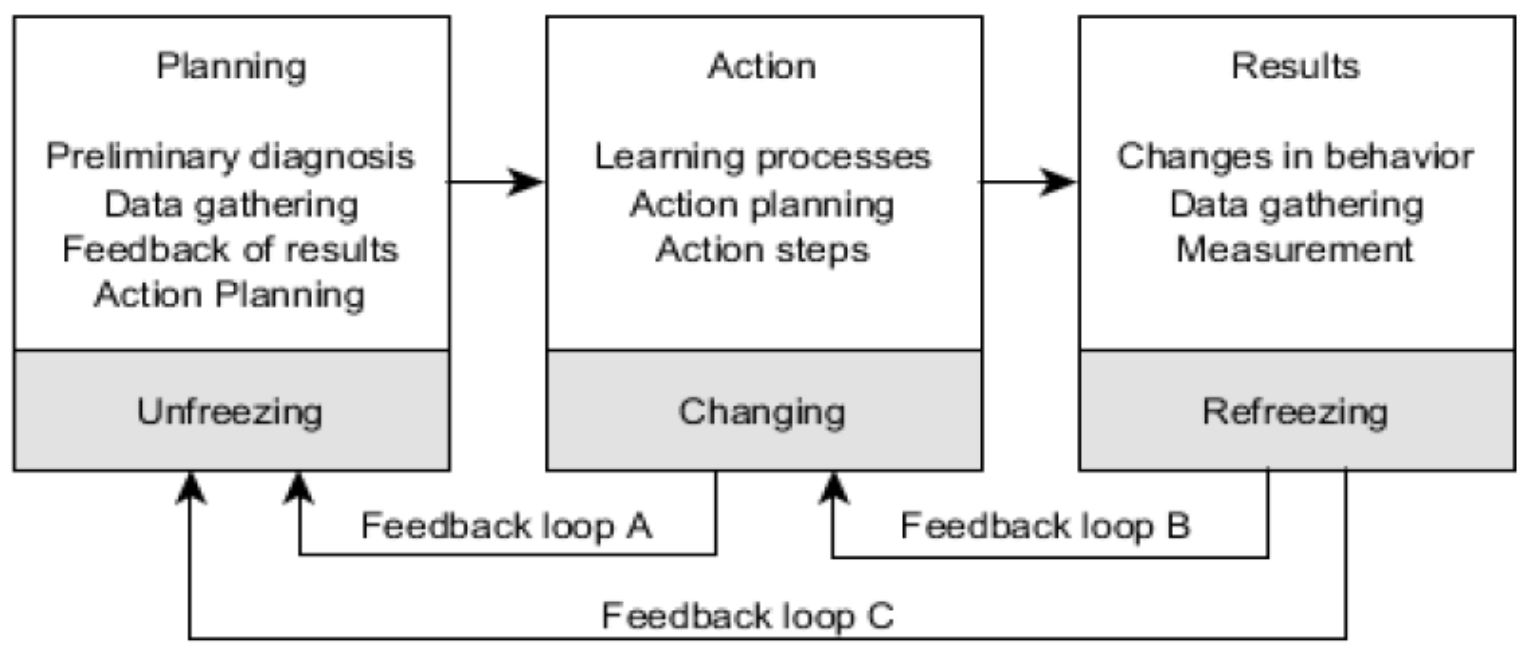

Figure 4: Lewin's change model (Lewin, 1947). 


\section{Research Methodology}

This study applied mixed method approach to make comparison on quantitative and qualitative data for accurate findings, reflect the ideas and opinions generated from respondents, enable interactions between scholar, provide flexibility in methodologies and enrich and complete the data collected (Wisdom \& Creswell, 2013). Questionnaires and interviews are conducted two times for data collection, which before and after the work from home intervention applied in a well-known local property developer.

Non-probability sampling method is applied in this study as only a focus group of sales and sales admin staffs will undergo the work-life balance intervention instead of the whole organization (Taherdoost, 2016). Purposive sampling method is applied as it is ideal for exploratory research design which specific group is selected in order to suit the study needs, while remained the time and cost to be effective (Saunders, Lewis \& Thornhill, 2009). Through the distribution of questionnaires and interviews via Google form, forty-two responses are collected in this study from a total of eighty sales and sales admin staffs for qualitative and quantitative analysis afterwards. Thirty respondents are low and middle management level staffs while twelve respondents are high management level staffs.

\section{Result and Discussion Qualitative Analysis}

Interview result from low and middle management level staffs indicated that work from home intervention is less effective to improve work-life balance and reduce turnover intention. Majority of the respondents feedbacked that the policy is less effective as long working hour, rigid company structure, pressure working environment and lack of managerial support still existed after the intervention is applied. Thus, most of them suggested flexible work arrangement, including flexible working space or working hour can be an alternative intervention to improve this situation in the future.

Interview result from high management level staffs indicated that half of them agreed with the low and middle management level staffs, where work from home intervention is not effective in this situation. However, remaining of them feedbacked that the organization is actually doing a great job in pursuing work-life balance for its staffs. Staffs should take own initiative in achieving work-life balance instead of company putting effort on it for the staffs only. Alternatively, the high management level staffs proposed that managerial support should present first in order to help the staffs in achieving work-life balance and reducing turnover intention, rather than implementing other interventions that might have the same outcome as work from home intervention if managerial support is absent.

\section{Quantitative Analysis}

Questionnaires are first analyzed through normality test and reliability test to test on the data normality and reliability. Although data collected skewed away slightly from the normal distribution, Shapiro-Wilk test result and Cronbach's alpha value showed that the data are significantly normal and reliable to continue further for the paired T-test. 
INTERNATIONAL JOURNAL OF ACADEMIC RESEARCH IN BUSINESS AND SOCIAL SCIENCES Vol. 11, No. 6, 2021, E-ISSN: 2222-6990 @ 2021 HRMARS

\begin{tabular}{|l|l|l|l|l|l|l|l|}
\hline No & Variable & Mean & $\mathrm{N}$ & $\begin{array}{l}\text { Std. } \\
\text { Deviation }\end{array}$ & Paired & $\begin{array}{l}\text { Paired } \\
\text { differences } \\
\text { (Mean) }\end{array}$ & $\begin{array}{l}\text { Sig. (2- } \\
\text { tailed) }\end{array}$ \\
\hline 1 & WORK & 3.8976 & 42 & 0.55808 & WORK-WORK1 & -0.4048 & 0.750 \\
\hline 2 & WORK1 & 3.9381 & 42 & 0.79233 & & & \\
\hline 3 & INTENTION & 3.5952 & 42 & 0.89877 & INTENTION- & -1.4524 & 0.346 \\
\cline { 1 - 5 } & INTENTION1 & 3.7405 & 42 & 1.06932 & INTENTION1 & & \\
\hline 5 & INTERVENTION & 3.7310 & 42 & 1.02707 & INTERVENTION- & 1.35714 & 0.000 \\
\cline { 1 - 4 } & INTERVENTION1 & 2.3738 & 42 & 0.98947 & INTERVENTION1 & & \\
\hline
\end{tabular}

Table 1: Paired T-test result.

Based on Table 1, the paired T-test is conducted before and after the intervention for all 3 pairs of variables, which tested the before and after intervention effect of work from home towards the work-life balance, turnover intention and work-from home effectiveness via the pair of WORK-WORK1, INTENTION-INTENTION1 and INTERVENTION-INTERVENTION1 respectively.

Surprisingly, the result obtained from paired-T test is contradicted to most of the recent studies' findings. At $5 \%$ level of significance, the respondents do not feel any significant improvement or changes in their work-life balance and turnover intention before and after the work from home intervention applied. Meanwhile, the respondents feel that work from home intervention is significantly not effective to solve this issue as the mean score of INTERVENTION-INTERVENTION1 has dropped for 1.35714 at $5 \%$ level of significance.

Based on the result obtained, the participants are said to be incapable in differentiating between work and private life, which causing a bigger conflict to occur in worklife balance. The work and private life seem to mix up as the working hour and working environment remained long and stressful due to the advanced technology that allowed the employees to work anytime when required so (Sarker, Ahuja \& Sarker, 2018). Besides that, Rasheed, lqbal and Mustafa (2018) stated that the absence of managerial support that led to the communication gap and higher priority to take care of family members compared to work will further worsen this situation, which discouraged the employees to fully utilize the benefits contributed by work from home intervention (Ahmad et al., 2016).

\section{Conclusion}

As studies conducted regarding work-life balance and employee turnover intention are very limited in Malaysia real estate market, this study contributed theoretically on how work from home can serve as an intervention to curb with this issue. This study also contributed practically on how work from home intervention will affect the work-life balance and turnover intention among the participants involved in the particular organization.

The result findings also recommended that future interventions shall focus on flexible work arrangements, while considering the element of managerial support in the interventions. According to Kumar et al. (2018), the presence of managerial support will help to fill the communication gap among employers and employees and promote satisfaction in job, which will reduce the turnover intention eventually. In related to this context, managerial support will help employers to understand on the importance of flexible work arrangements 
and support such interventions, which will allow better interventions to be made toward the employees without any obstacle. As such, the work-life balance and turnover intention among the employees is expected to be improved when flexible work arrangements are applied.

To conclude, as human capital is defined as the most important asset that determined the future of a company, it is essential for a company to understand on how to retain such valuable resource in the company for future growth (Fulmer \& Ployhart, 2014). It is important to prioritize work-life balance among the talents in order to promote healthy working environment and refrain employees from leaving the company (Kohll, 2018). Thus, companies in real estate market shall adapt various interventions in order to manage turnover intention and work-life balance effectively.

\section{References}

Ahmad, A., Shaw, N. E., Bown, N. J., Gardiner, J., \& Omar, K. (2016). The impact of negative work home interface on intention to leave and the role of flexible working arrangements in Malaysia. The Journal of Developing Areas, 50(5), 507-515.

Airmas Group. (2020). What are Schedule G and H? - Tips for First Time Home Buyers. Retrieved from https://airmas.com/home/news-details/26/what-are-schedule-g-andh?---tips-for-first-time-home-buyers_601317

Ali, S., Amin, S. M., \& Hamid, R. A. (2016). A Review on Relationship between Reward and Turnover Intention. Journal of Advanced Review on Scientific Research, 19(1), 1-16.

Akinyele, S. T., Peters, M. C., \& Akinyele, F. E. (2016). Work-life balance practices as panacea for employee performance: empirical evidence from river state television, Nigeria. Oman Chapter of Arabian Journal of Business and Management Review, 34(92), 1-14.

Amponsah, M., \& Afram, K. O. A. O. (2018). The Role of Work Life Balance on Employee Commitment and Turnover Intentions: A Study of Tertiary Institution Workers. JEP, 9(30).

Arshad, H., \& Puteh, F. (2015). Determinants of turnover intention among employees. Journal of Administrative Science, 12(2), 1-15.

Arumugam, T. (2020). More taking on tough jobs to survive. Retrieved from https://www.nst.com.my/news/nation/2020/08/613564/more-taking-tough-jobssurvive

Bass, J. M., Sarah, B., Razzak, M. A., \& Noll, J. (2018). Employee retention and turnover in global software development: comparing in-house offshoring and offshore outsourcing. In 2018 IEEE/ACM 13th International Conference on Global Software Engineering (ICGSE) (pp. 77-86). IEEE.

Bupalan, G. (2017). Understanding the four fundamental bumi attributes in M'sian property. Retrieved from https://themalaysianreserve.com/2017/05/24/understanding-the-fourfundamental-bumi-attributes-in-malaysian-property/

Cain, L., Busser, J., \& Kang, H. J. A. (2018). Executive chefs' calling: effect on engagement, work-life balance and life satisfaction. International Journal of Contemporary Hospitality Management.

Carlson, D. S., Thompson, M. J., Crawford, W. S., \& Kacmar, K. M. (2019). Spillover and crossover of work resources: A test of the positive flow of resources through work-family enrichment. Journal of Organizational Behavior, 40(6), 709-722. 
Chandran, S. (2017). Projecting women leaders who inspire. Retrieved from https://www.thestar.com.my/news/nation/2017/02/26/projecting-women-leaderswho-inspire-ecoworld-summit-to-celebrate-female-professionals-from-all-walk

Chemirmir, M. J., Musebe, R., \& Nassiuma, B. K. (2018). The Role Of Work Life Balance On Employee Turnover In The Flower Industry In The North Rift Kenya. International Journal of Research in Social Sciences and Humanities.

Clark, S. C. (2000). Work/family border theory: A new theory of work/family balance. Human relations, 53(6), 747-770.

Creswell, J. W., \& Clark, V. L. P. (2017). Designing and conducting mixed methods research. Sage publications.

Cummings, S., Bridgman, T., \& Brown, K. G. (2016). Unfreezing change as three steps: Rethinking Kurt Lewin's legacy for change management. Human relations, 69(1), 33-60.

Delice, A. (2010). The Sampling Issues in Quantitative Research. Educational Sciences: Theory and Practice, 10(4), 2001-2018.

Denise, C. (2017). How does Malaysia ensure that its buildings are safe to use?. Retrieved from https://asklegal.my/p/how-does-malaysia-ensure-that-its-buildings-are-safe-tolive-in

Dockery, A. M., \& Bawa, S. (2014). Is working from home good work or bad work? Evidence from Australian employees. Australian Journal of Labour Economics, 17(2), 163.

Dudovskiy, J. (2016). The ultimate guide to writing a dissertation in business studies: a stepby-step assistance. Pittsburgh, USA.

Dzulkifly, D. (2020). Higher education minister foresees 75,000 fresh grads struggling to get jobs in Covid-19 era. Retrieved from https://www.malaymail.com/news/malaysia/2020/09/28/higher-education-ministerforesees-75000-fresh-grads-struggling-to-get-

jobs/1907493\#: :text=\%E2\%80\%9CIn\%202020\%2C\%20it\%20is\%20estimated,six\%20mo nths\%20after\%20they\%20graduated.

Einstein, A., Addams, J., \& Roosevelt, E. (2016). Maslow's hierarchy of needs.

Falak, A. (2020). Malaysia's PENJANA Stimulus Package: Key Features. Retrieved from https://www.aseanbriefing.com/news/malaysias-penjana-stimulus-package-keyfeatures/

Fitria, Y., \& Linda, M. R. (2019). Perceived Organizational Support and Work Life Balance on Employee Turnover Intention. In 1st International Conference on Economics, Business, Entrepreneurship, and Finance (ICEBEF 2018). Atlantis Press.

Frue, K. (2020). Malaysia's PESTEL analysis Focuses on the Country's Needs. Retrieved from https://pestleanalysis.com/malaysia-pestel-analysis/

Fulmer, I. S., \& Ployhart, R. E. (2014). "Our Most Important Asset" a multidisciplinary/multilevel review of human capital valuation for research and practice. Journal of Management, 40(1), 161-192.

FundMyHome. (2019). About FundMyHome. Retrieved from https://www.fundmyhome.com/about

Ganeshwaran. (2019). House prices beyond affordability of most Malaysians. Retrieved from https://www.thestar.com.my/business/business-news/2019/10/25/house-pricesbeyond-affordability-of-most-malaysians

Glassdoor Inc. (2020). Eco World Development Group Reviews. Retrieved from https://www.glassdoor.com/Reviews/Eco-World-Development-Group-ReviewsE1381752.htm 
Harden, G., Boakye, K. G., \& Ryan, S. (2018). Turnover intention of technology professionals: A social exchange theory perspective. Journal of Computer Information Systems, 58(4), 291-300.

Hartzell, S. (2020). Lewin's 3-Stage Model of Change: Unfreezing, Changing \& Refreezing. Retrieved from https://study.com/academy/lesson/lewins-3-stage-model-of-changeunfreezing-changing refreezing.html\#: :text=Kurt\%20Lewin\%20developed\%20a\%20change,\%3A\%20unfreezi ng\%2C\%20changing\%20and\%20refreezing.\&text=For\%20Lewin\%2C\%20the\%20process \%20of,new\%20behavior\%20as\%20the\%20norm.

Hassan, M. M., Jambulingam, M., Alam, M. N., \& Islam, M. S. (2019). Redesigning the Retention Strategy Against the Emerging Turnover of Generation Y: Revisiting the LongStanding Problems from 20th to 21st Century. International Journal of Entrepreneurship.

Hee, O. C., \& Ann, Y. S. (2019). Factors Influencing Employee Turnover in the Food Manufacturing Industry in Malaysia. INTERNATIONAL JOURNAL OF ACADEMIC RESEARCH IN BUSINESS AND SOCIAL SCIENCES, 9(1).

Hill, T., \& Westbrook, R. (1997). SWOT analysis: it's time for a product recall. Long range planning, 30(1), 46-52.

Hobbs, M., Klachky, E., \& Cooper, M. (2020). Job satisfaction assessments of agricultural workers help employers improve the work environment and reduce turnover. California Agriculture, 74(1), 30-39.

Idris, A. N. (2020). Sluggish property market conditions to continue in 2020 - analysts. Retrieved from https://www.theedgemarkets.com/article/sluggish-property-marketconditions-continue-2020-\%E2\%80\%94-analysts

Iriste, S., \& Katane, I. (2018). Expertise as a research method in education. Rural Environ. Educ. Personal, 11, 74-80.

Jago, L., \& Deery, M. (2015). Revisiting talent management, work-life balance and retention strategies. International Journal of Contemporary Hospitality Management, 27(3), 453472.

Jain, S. (2013). Questionnaire on work life balance for working parents. Retrieved from https://www.slideshare.net/SheetalJain9/questionnaire-on-work-life-balance-forworking-parents

Jaharuddin, N. S., \& Zainol, L. N. (2019). The Impact of Work-Life Balance on Job Engagement and Turnover Intention. The South East Asian Journal of Management.

Jurevicius, O. (2013). PEST \& PESTEL Analysis. Retrieved from https://strategicmanagementinsight.com/tools/pest-pestel-analysis.html

Kamarulzaman. F. (2020). Teleworking increases productivity, reduces employee turnover, absenteeism. Retrieved from https://www.malaymail.com/news/what-youthink/2020/04/13/teleworking-increases-productivity-reduces-employee-turnoverabsenteeism-fa/1856243

Kathy, B. (2019). Public schemes offer affordable properties. Retrieved from https://www.nst.com.my/property/2019/09/522558/public-schemes-offer-affordableproperties

Khoo, E., \& Chung, Y. Y. (2020). Cover Story: Property market outlook and opportunities in times of uncertainty. Retrieved from https://www.theedgemarkets.com/article/coverstory-property-market-outlook-and-opportunities-times-uncertainty

Kim, H. Y. (2013). Statistical notes for clinical researchers: assessing normal distribution (2) using skewness and kurtosis. Restorative dentistry \& endodontics, 38(1), 52-54. 
Kohll, A. (2018). The Evolving Definition Of Work-Life Balance. Retrieved from https://www.forbes.com/sites/alankohll/2018/03/27/the-evolving-definition-of-worklife-balance/?sh=160910159ed3

Kopperud, K. H., Nerstad, C. G., \& Dysvik, A. (2020). Should i stay or should i go? The role of motivational climate and work-home spillover for turnover intentions. Frontiers in Psychology, 11, 1107.

Kozuch, K. (2020). Best smart home devices of 2020. Retrieved from https://www.tomsguide.com/us/best-smart-home-devices, review-2008.html

Kroll, C., \& Nuesch, S. (2019). The effects of flexible work practices on employee attitudes: evidence from a large-scale panel study in Germany. The International Journal of Human Resource Management, 30(9), 1505-1525.

Kumar, M., Jauhari, H., Rastogi, A., \& Sivakumar, S. (2018). Managerial support for development and turnover intention. Journal of organizational change management.

Lahti, A. (2017). The perceived impact of flexible working hours on work-life balance in the educational sector in Finland: a qualitative research study.

Lewin, K. (1947). Group decision and social change. Readings in social psychology, 3(1), 197-211.

Lu, C. C., Ting, Y. S., \& Hsu, Y. L. (2016). The Review of Work and Family Balance among Employees in Hospitality Industry in Taiwan. International Business Research, 9(9), 51-57.

McDonald, J. H. (2009). Handbook of biological statistics (Vol. 2, pp. 6-59). Baltimore, MD: sparky house publishing.

Melnikovas, A. (2018). Towards an explicit research methodology: Adapting research onion model for futures studies. Journal of Futures Studies, 23(2), 29-44.

Middleton, F. (2020). Reliability vs validity: what's the difference? Retrieved from https://www.scribbr.com/methodology/reliability-vs-validity/

New Straits Times. (2020). Malaysia's political crisis - As it unfolds. Retrieved from https://www.nst.com.my/news/nation/2020/02/569836/malaysias-political-crisis-itunfolds

Nolan, L. S. (2015). The Roar of Millennials: Retaining Top Talent in the Workplace. Journal of Leadership, Accountability \& Ethics, 12(5).

NST Business. (2020). EcoWorld registers strongest quarterly sales in Q4. Retrieved from https://www.nst.com.my/business/2020/12/650204/ecoworld-registers-strongestquarterly-salesq4\#: :text=Liew\%20said\%20for\%20financial\%20year,sales\%20target\%20of\%20RM5\%20 billion.

Oosthuizen, R. M., Coetzee, M., \& Munro, Z. (2016). Work-life balance, job satisfaction and turnover intention amongst information technology employees. Southern African Business Review, 20(1), 446-467.

Pallant, J. (2020). SPSS survival manual: A step by step guide to data analysis using IBM SPSS. Routledge.

Povera, A., \& Harun, H. N. (2020). Dr Noor Hisham: Six criteria must be met before MCO is lifted. Retrieved from https://www.nst.com.my/news/nation/2020/04/586369/dr-noorhisham-six-criteria-must-be-met-mco-lifted

PropertyGuru International (Malaysia) Sdn Bhd. (2020). Should You Buy A HOC Project? Consider These Pros And Cons! Retrieved from https://www.propertyguru.com.my/property-guides/should-you-buy-a-homeownership-campaign-hoc-project-pros-and-cons-30905 
Rahman, R. A., Mustaffa, W. S. W., Rhouse, S. M., \& Ab Wahid, H. (2016). Work Challenges and coping strategies of professional and managerial dual-career couples in Malaysia. International Journal of Academic Research in Business and Social Sciences, 6(12), 256-271.

Rajendran, N., Watt, H. M., \& Richardson, P. W. (2020). Teacher burnout and turnover intent. The Australian Educational Researcher, 47(3), 477-500.

Rasheed, M., Iqbal, S., \& Mustafa, F. (2018). Work-family conflict and female employees' turnover intentions. Gender in Management: An International Journal.

Raza, B., Ali, M., Naseem, K., Moeed, A., Ahmed, J., \& Hamid, M. (2018). Impact of trait mindfulness on job satisfaction and turnover intentions: Mediating role of work-family balance and moderating role of work-family conflict. Cogent Business \& Management, 5(1), 1542943.

Razali, N. M., \& Wah, Y. B. (2011). Power comparisons of shapiro-wilk, kolmogorov-smirnov, lilliefors and anderson-darling tests. Journal of statistical modeling and analytics, 2(1), 21-33.

Rouse, M. (2019). fishbone diagram (Ishikawa cause and effect). Retrieved from https://whatis.techtarget.com/definition/fishbone-diagram

Salkind, N. J. (Ed.). (2010). Encyclopedia of research design (Vol. 1). Sage.

Sarker, S., Ahuja, M., \& Sarker, S. (2018). Work-life conflict of globally distributed software development personnel: An empirical investigation using border theory. Information Systems Research, 29(1), 103-126.

Saunders, M., Lewis, P., \& Thornhill, A. (2009). Research methods for business students. Pearson education.

Seyrek, I. H., \& Turan, A. (2017). Effects of Individual Characteristics and Work Related Factors on the Turnover Intention of Accounting Professionals. International Journal of Academic Research in Accounting, Finance and Management Sciences, 7(1), 236-244.

Shockley, K. M., Smith, C. R., \& Knudsen, E. A. (2017). The Impact of Work-Life Balance on Employee Retention. The Wiley Blackwell Handbook of the Psychology of Recruitment, Selection and Employee Retention, 513-543.

Sok, J., Blomme, R. J., De Ruiter, M., Tromp, D., \& Lub, X. D. (2018). Home to work spillover and turnover intentions. European Journal of Training and Development.

Star Media Group Berhad. (2020). Malaysia King names Muhyiddin as Premier to succeed Mahathir. Retrieved from https://www.thestar.com.my/news/regional/2020/02/29/malaysia-king-namesmuhyiddin-as-premier-to-succeed-mahathir

Stroup, C., \& Yoon, J. (2016). What Impact do Flexible Working Arrangements (FWA) have on Employee Performance and Overall Business Results?.

Supriya, S. (2020). Cover Story: Deflated salary expectations for 2021. Retrieved from https://www.theedgemarkets.com/article/cover-story-deflated-salary-expectations2021

Swaen, B. (2019). How do you determine the quality of a journal article? Retrieved from https://www.scribbr.com/tips/how-do-you-determine-the-quality-of-a-journal-article/

Syafiqah, S. (2020). Ex-EcoWorld ED Voon Tin Yow is now IOI Properties CEO. Retrieved from https://www.theedgemarkets.com/article/execoworld-ed-voon-tin-yow-now-ioiproperties-ceo

Taber, K. S. (2017). The Use of Cronbach's Alpha When Developing and Reporting Research Instruments in Science Education. Research in Science Education, 1-24. 
Taherdoost, H. (2016). Sampling methods in research methodology; how to choose a sampling technique for research. How to Choose a Sampling Technique for Research (April 10, 2016).

Takeuchi, M. (2017). Effects of Work-Life Balance Policies on Female Commitment towards the Same Company. International Journal of Business Administration, 8(7), 139-153.

Tan, R. (2019). Diversity and inclusion - Eco World's way. Retrieved from https://www.thestar.com.my/business/business-news/2019/07/27/diversity-andinclusion--eco-worlds-way

Tan-Wilson, A., \& Stamp, N. (2015). College students' views of work-life balance in STEM research careers: Addressing negative preconceptions. CBE-Life Sciences Education, 14(3), es5.

Thakur, S. J., \& Bhatnagar, J. (2017). Mediator analysis of job embeddedness. Employee Relations.

Van Teijlingen, E. R., \& Hundley, V. (2001). The importance of pilot studies.

Wisdom, J., \& Creswell, J. W. (2013). Mixed methods: integrating quantitative and qualitative data collection and analysis while studying patient-centered medical home models. Rockville: Agency for Healthcare Research and Quality. 